DOI: http://doi.org/10.22364/cl.69.7

\title{
VECĀS DERĪBAS ANTROPOLOĢIJA 20. UN 21. GADSIMTĀ
}

\author{
Jānis Rudzītis-Neimanis \\ Dr. theol., LU Teologiijas fakultātes docents
}

Jautājums par to, kas ir cilvēks, ir mūžsens - to uzdod katrs cilvēks. Vai uz šo jautājumu vispār var atbildēt? Atbildes uz šo jautājumu ir mainījušās laika gaitā, tāpat kā ir mainījusies Vecās Derības teolog̣ija un tās interese par cilvēku. Raksta mērksis ir izsekot Vecās Derības teologijas interesei aptuveni pēdējo 100 gadu laikā.

\section{Vecās Derības antropoloğija 20. gadsimtā}

Lai arī daudzās dogmatikas grāmatās atrodamas nodaḷas, kuru nosaukumos ir sastopams vārds "antropologija” ("mācība par cilvēku" nozīmē), tomēr specifiski par Vecās Derības (turpmāk VD) antropolog̣iju var runāt tikai kopš 19. gs., kad pēc garāka atdalīšanās procesa ${ }^{1}$ VD teologija izveidojās par atsevišksu teolog̣ijas apakšnozari. Var piekrist Andreasam Vāgneram (Andreas Wagner), ka antropoloğija 20. gs. piedzīvojusi ritmisku attīstību ar vidēji 30 gadu ciklu - dažādi nopietni satricinājumi (kari) vai izaicinājumi (globālās izmaiṇas 20./21. gs. mijā) sekmēja pievēršanos vienam vai otram fenomenam. ${ }^{2}$ Katram pārmaiņu periodam ir raksturīgi jauni antropologiski

1 Pēc sākotnējās atdalīšanās no dogmatikas Bībeles teologija vēlāk sadalījās divās apakšnozarēs.

2 Andreas Wagner, "Anthropologie(n) des Alten Testaments im 21. Jahrhundert," in: Andreas Wagner (Hg.), Menschenverständnis und Gottesverständnis im Alten Testament (Göttingen: Vandenhoeck \& Ruprecht, 2016), 3. 
meklējumi (dažādi vērtējot cilvēka vietu pasaulē, viņa spējas, uzdevumus u. tml.).

Līdz Otrajam pasaules karam pakāpeniski pieauga to pētījumu skaits, kuros bez tradicionāli dogmatikā apskatītajiem VD tekstiem (piem., 1Moz 1-3, Ps 8 u. c.) centās aptvert pēc iespējas vairāk VD tekstu, kuros parādās priekšstati par cilvēku. 19. gs. beigu / 20. gs. sākuma darbiem ir novērojama interese par Seno Austrumu kultūrām un to ietekmi uz VD tekstiem. Atklājot citas Seno Austrumu kultūras, jau 19. gs. tika jautāts, vai senajiem izraēliešiem nebija kopīgs pasaules redzējums ar šìm tautām (arī par cilvēku)?

Šveiciešu teologu Alfrēdu Bertolē (Alfred Bertholet) var uzskatīt par raksturīgu šī laika pārstāvi, kurš darbojās gan VD teologiijas, gan relig̣ijpētniecības jomā. Vienā no saviem zināmākajiem darbiem (Kulturgeschichte Israels) Bertolē vairākas nodaļas velta izteikti antropolog̣iskiem jautājumiem (seno izraēliešu ǵimenes dzīve, nodarbošanās, sociālā, politiskā, garīgā dzīve). ${ }^{3}$ Kādā citā darbā šveiciešu teologs pēta konkrētus VD sastopamus priekšstatus par nāvi un cilvēka stāvokli pēc nāves $^{4}$. Lai tos saprastu, Bertolē analizē VD atrodamās norādes par apiešanos ar cilvēka ķ่ermeni dzīves laikā un pēc nāves.

Vairāki šajā laikposmā tapuši darbi, kuru autori pievēršas izteikti teoloğiskiem aspektiem, būtiski ietekmē turpmāko pētniecību. Piemēram, jau 19. gs. beigās Gustavs Ēlers (Gustav F. Oehler) noraidīja izplatīto priekšstatu par dihotomisko vai trihotomisko cilvēka būtību. Analizējot VD bieži sastopamos antropoloǵiskos terminus (nefeš, bāsār u. c.), Ēlers secināja, ka VD dominē holistisks cilvēka redzējums un ar šiem terminiem visdrīzāk ir domāts cilvēks kopumā. ${ }^{5}$ Johanness Pedersens (Johannes Pedersen) apjomīgajā pētījumā Israel. Its Life and culture $^{6}$ padziḷināti pievēršas nefeš nozīmes noskaidrošanai. Par pamatu ņemot $1 \mathrm{Moz} 2$ tekstu, Pedersens secina, ka cilvēks

${ }^{3}$ Alfred Bertholet, Kulturgeschichte Israels (Göttingen: Vandenhoeck \& Ruprecht, 1919).

${ }_{4}$ Alfred Bertholet, Die israelitischen Vorstellungen vom Zustand nach dem Tode (Tübingen: Mohr, 1914).

5 Gustav F. Oehler, Theologie des Alten Testaments (Stuttgart: J. F. Steinkopf, 1891).

6 Johannes Pedersen, Israel, Its Life and Culture (London: Oxford University Press, 1926). 
pēc elpas iepūšanas "kḷuva par dzīvu dvēseli" (t. i., pats cilvēks ir dvēsele), tādā veidā mēǵinot atrisināt tās sarežğìtās VD vietas, kur nefeš mirst vai ir izsalkusi, tiesa, viņš neapskata tos VD tekstus, kas neder viņa teorijai. Psihoanalīzes u. c. psihologijas virzienu ietekmē parādījās gan antropologiski darbi par kāda konkrēta VD personāža psihologisko portretu, gan t. s. ideālā senā izraēlieša biogrāfijas. ${ }^{7}$

Pirmajā dekādē pēc Otrā pasaules kara tapa darbi, kuru mērķis bija pievērsties plašākam lasītāju lokam, lai ar vispārējām antropolog̣ijas tēmām mainītu kara radītos izkropḷojumus priekšstatos par cilvēku. Daudzi (īpaši vāciski rakstošie) teologi par savu uzdevumu uzskatīja nepieciešamību meklēt jaunus veidus, kā uzrunāt cilvēkus, kā saprast cilvēka būtību un sūtību, tāpēc šajā laikā tapušajiem darbiem par VD antropologiju pārsvarā ir raksturīgs neliels apjoms un vienkārša, saprotama valoda. ${ }^{8}$ Pamācošs ir Valtera Eihroda (Walter Eichrodt) gadījums. Savā darbā, kurā aplūkoti priekšstati par cilvēku VD, ${ }^{9}$ Eihrods kritizē nacionālsociālisma attieksmi pret VD un Bībeli kopumā, taču zīmīgi, ka Eihrods 10 gadus agrāk publicēja nelielu darbu par antisemītismu ${ }^{10}$, kurā, lai arī kritizē "jūdu rases" koncepciju kā aplamu, tomēr atzīst, ka antisemītisms pastāv daḷeji arī pašu jūdu vainas dẹl̦ (VD par to liecinot Esteres grāmata). ${ }^{11}$

Ar klasisko Hansa Valtera Volfa (Hans Walter Wolff) monogrāfiju par VD antropolog̣iju' ${ }^{12}$ VD teologiija nopietni sāk pievērsties cilvēka miesiskajiem aspektiem un to teologiskai atspogul̦ošanai VD. Lai gan priekšdarbus jau dal̦eji bija paveikuši Volfa priekšgājēji, tomēr tieši viņa darbs uzskatāmi parādīja, ka termini cilvēka ķ̣ermeņa daļu apzīmēšanai uzsver ko vairāk nekā ķ kermenisko aspektu. Volfa pētījums pasvītroja, ka VD ir

7 Johannes Hempel, Gott und Mensch im Alten Testament (Stuttgart: Kohlhammer, 1936).

8 Piemēram, Kurt Galling, Das Bild vom Menschen in biblischer Sicht (Mainz: Kupferberg, 1947).

9 Walter Eichrodt, Das Menschenverständnis des Alten Testament (Zürich: Zwingli Verlag, 1947).

10 Walter Eichrodt, Antisemitismus in alter und neuer Zeit (Zürich: Zwingli Verlag, 1937).

11 Eichrodt, Antisemitismus, 25-26.

12 Hans Walter Wolff, Anthropologie des Alten Testaments (München: Chr. Kaiser Verlag, 1973). 
vienlīdz daudz pārstāvēti cilvēka fizioloǵiskie, emocionālie, sociālie un psiholoğiskie aspekti. Vēl viens svarīgs Volfa monogrāfijas secinājums ir cilvēka k̦ermeņa uztveres ${ }^{13}$ un pieredzes nesaraujamā saikne ar dažādiem materiāliem aspektiem.

Volfs izvirza mērķi noskaidrot, kā VD tiek uzdots jautājums par cilvēka būtību un kā tas tiek atbildēts (kā cilvēks nonāk pie atziņas, kas viņš ir). ${ }^{14}$ Tāpēc Volfs analizē tikai tos VD tekstus, kuri skaidri runā par to, turklāt Volfs neaplūko iespējamo antropologiisko priekšstatu attīstību VD ietvaros.

Volfs uzskata, ka kvalitatīvs darbs par VD antropolog̣iju ir iespējams tikai tad, ja tas ir veikts detalizēti un ar daudzu piemēru palīdzību (aplūkojot raksturīgus piemērus, neizlaižot svarīgo, papildinot ar specifiskiem gadijjumiem). Volfa monogrāfijā atbalsojas tālaika diskusija VD teologijāă, ko izraisīja Gerharda fon Rāda (Gerhard von Rad) sarakstītā VD teoloğija ${ }^{15}$, kur ar t. s. VD centra idejas noraidīšanu tika pasvītrots VD tekstu pārstāvēto tradīciju daudzveidīgums. Volfs to izmanto, lai parādītu, ka VD nav vienotas mācības par cilvēku un nav iespējams rekonstruēt VD antropoloǵisko priekšstatu lineāru attīstību. ${ }^{16}$ Neskatoties uz Volfa skepsi par vienotas VD antropolog̣ijas iespējamību, pats darbs satur mēg̣inājumu to paveikt, tas izpaužas monogrāfijas struktūrā. ${ }^{17}$ Volfa

13 Volfs darbā plašāk neizvērš k̦ermeņa dzimuma aspektu, jo viņš vēl domā universālās kategorijās, par ko izpelnījās vairāku teologu kritiku par netiešo androcentrismu. Erhards Gerstenbergers (Erhard Gerstenberger) norāda, ka Volfs ne vienmēr apzinājās patriarhālās sabiedrības sociālās struktūras, tāpēc drīzāk tā būtu jādēvē nevis par VD antropologiiju, bet gan par VD andrologiju (Erhard Gerstenberger, "Herrschen oder Lieben: Zum Verhältnis der Geschlechter im Alten Testament," in Jörg Jeremias (Hg.), Die Botschaft und die Boten (Neukirchen-Vluyn: Neukirchener Verlag, 1981), 335-347).

14 Wolff, op. cit., 5, 17. Jāatzīst, ka šāda interese ir raksturīga arī dažām vēlākām citu teologu publikācijām, piemēram: Werner H. Schmidt, Einführung in das Alte Testament (Berlin: de Gruyter, 1995), 394.

15 Gerhard von Rad, Theologie des Alten Testaments, B. 1-2. (München: Chr. Kaiser Verlag, 1957, 1960).

16 Wolff, op. cit., 16. Pretējos uzskatos bija Ludvigs Kēlers (Ludwig Köhler): Ludwig Köhler, Der hebräische Mensch (Tübingen: Mohr, 1953), 2.

17 Volfa darba 3 daḷas ir: 1) cilvēka būtība (antropologisiskās valodas mācība); 2) cilvēka laiks (biogrāfiskā antropolog̣ija); 3) cilvēka pasaule (sociolog̣ijas antropolog̣ija). Volfs, apskatot centrālos antropolog̣ijas jēdzienus VD, neaizmirst arī citus VD sastopamos antropolog̣ijas jēdzienus, taču Volfs pasvītro auss/dzirdes prioritāti (iepretī acij/redzei), kas nekādi neatbilst 
klasifikācija antropolog̣iskajos pamatterminos un pārējos terminos vēlāk tika kritizēta, tomēr jāatceras, ka to var uztvert arī kā atbildi Torleifam Bomanam (Thorleif Boman) ${ }^{18}$ un atbildi uz to, ka vinsš VD sastopamos priekšstatus salīdzinājis ar priekšstatiem grieķu klasiskajā kultūrā. Atsevišksu tēmu trūkums reizēm ir izskaidrojams ar Volfa kritēriju analizēt tikai tos VD tekstus, kuri paši jautā/runā par cilvēku. ${ }^{19}$ Neskatoties uz šiem dažiem trūkumiem, Volfa monogrāfija kopumā saņēma pozitīvas atsauksmes un ilgu laiku bija atskaites punkts dažādiem antropoloǵiskiem pētījumiem par VD. Tajos lielā mērā tika padziḷinātas Volfa monogrāfijas pamatnostādnes (atbilstoši grāmatas dạ̦ām - antropolog̣iskā valoda, biogrāfiskā antropoloǵija, socioloǵiskā antropolog̣ija), nereti saliekot arī citus akcentus. Piemēram, spēcīga Volfa monogrāfijas ietekme ir vērojama Horsta Dïtriha Preisa (Horst Dietrich Preuß) darba struktūrā un tēmu izvēlē: 1) cilvēks kā radība (biolog̣iskā un biogrāfiskā); 2) cilvēks dažādās tekstu grupu liecībās; 3) dzīve, nāve un augšāmcelšanās; 4) cilvēks Dieva priekšā; 5) grēks un vaina; 6) piedošana un izlīgums. ${ }^{20}$

Aptuveni šajā laikā notiek arī antropologiiskais pagrieziens VD teolog̣ijā, piemēram, 1985. gadā Bernhards Langs (Bernhard Lang) mēgina VD teologijijā adaptēt kultūras antropologijas rezultātus (galvenokārt priekšstatus par telpu un laiku). ${ }^{21}$ Aizvien vairāk darbos VD antropologijas jomā vēsturiski tiek pētīta cilvēku rīcība, domāšana, emocijas u. c. Ar to ši pieeja atšksiras no filozofiskās antropolog̣ijas, kas jautā par cilvēka būtību un cilvēka eksistences nosacījumiem. VD antropologijijas

šo terminu biežumam VD. Cilvēka biogrāfija drīzāk atbilst tālaika vīrieša dzīvei no dzimšanas līdz nāves brīdim. Sociālā dzīve ietver ǵimeni, draugus, ienaidniekus, kungus un vergus (trūkst tautas aspekta). Tas pats attiecas arī uz sīkāko dalījumu 25 nodaḷās, reprezentējot autora subjektīvo redzējumu, par ko vēlāk tiek kritizēts. Plašāk par Volfa kritiku skat.: Silvia Schroer, Thomas Staubli, Die Körpersymbolik der Bibel, 2. Aufl. (Gütersloh: Gütersloher Verlagshaus, 2005), 16.

18 Thorleif Bomann, Das hebräische Denken im Vergleich mit dem griechischen (Göttingen: Vandenhoeck \& Ruprecht, 1952).

19 Wolff, Anthropologie, 17.

20 Horst Dietrich Preuß, Theologie des Alten Testaments (Stuttgart: Kohlhammer, 1992), 2: 116-121.

${ }_{21}$ Bernhard Lang, Anthropological Approaches to the Old Testament (Philadelphia: Fortress Press), 1985. 
gadījumā šie jautājumi arī tiek atbildēti, taču ņemot vērā specifiskos reliǵiskos, sociālos un mentalitātes aspektus.

Kopš 20. gs. 80. gadiem strauji pieaug pētījumu skaits par sieviešu dzīvi un to atainojumu VD. Piemēram, Silvijas Šroeres (Silvia Schroer) un Tomasa Štaubli (Thomas Staubli) kopīgi sarakstītā grāmata ${ }^{22}$ ne tik daudz piedāvā detalizētu filologisisku antropologiisko terminu analīzi, cik apskata šos terminus plašākā kontekstā (salīdzina tos ar Seno Austrumu un Jaunās Derības tekstiem, kā arī mūsdienu priekšstatiem), un dažās nodaḷās autori atsevišksi aplūko VD tekstus par sievietes k̉ermeni. Grāmatu tekstu papildina konkrēto ķermeņu daļu attēlojumi no attiecīgā laikposma. Pētniecībā aizvien biežāk sāk apzināties, ka kultūra, kas pieder pagātnei un tieši klātesot nav novērojama, tomēr ir atstājusi liecības par sevi, tāpēc arī simboliski cilvēka attēlojumi ir uzskatāmi par informācijas avotu, kas lauj atšifrēt Seno Austrumu priekšstatus par cilvēkiem.

Noslēdzot pārskatu par VD antropologiju 20. gs., noteikti ir jāpiemin cits Heidelbergas Universitātes profesors Klauss Vestermans (Claus Westermann). Cilvēku VD Vestermans aplūko gan kā radību, gan kā vēsturisku būtni, pieskaroties dažādiem cilvēka eksistences aspektiem (dzīves telpa, cilvēka mūžs, darbs, sabiedrība, pārtika, radība starp radībām, cilvēks Dieva priekšā) un noslēdzot darbu ar refleksiju par valodu un domāšanu. ${ }^{23}$ Vestermans precīzi raksturo trūkumus 20. gs. VD antropoloǵijas pētniecībā - līdzšinējā pētniecība pārāk maz uzmanības ir veltījusi VD cilvēka domāšanas izpētei. Savu priekšstatu projicēšana uz VD tekstiem aizēno VD raksturīgo domāšanu (piem., ètikas jautājumos). Vestermans ir kritisks pret antropologiskiem pētījumiem par VD, ja tie ir veidoti pēc sistemātiskai teolog̣ijai raksturīgās darbu uzbūves. Piemēram, lai gan abi iepriekš minētie autori Volfs un Preiss atzīst, ka VD nav vienotas mācības par cilvēku, nav sistemātiskas antropologijas, tomēr viņi mēgina rakstīt VD antropoloǵiju, lai gan katrā atsevišksā VD tekstā ir konkrēts redzējums par cilvēku. ${ }^{24}$

22 Silvia Schroer, Thomas Staubli, Die Körpersymbolik der Bibel, 2. Aufl. (Gütersloh: Gütersloher Verlagshaus, 2005).

23 Claus Westermann, Der Mensch im Alten Testament (Münster: LIT Verlag, 2000).

${ }_{24}$ Westermann, op. cit., 27. Vestermans atzīst, ka viņš ir uzrakstījis nevis VD antropologiju, bet gan eseju par cilvēku VD. 


\section{1. gadsimta tendences Vecās Derības antropologijijā}

20. gs. runāja par antropolog̣isko pagriezienu (anthropological turn) humanitārajās zinātnēs, bet 21. gs. sākumā jau runā par antropoloǵisko atgriešanos (anthropological return), kas teologiijas kontekstā nozīmētu atgriešanos pie antropoloǵiskajiem pamatjautājumiem. Strauji mainīgā situācija pasaulē, demogrāfiskie izaicinājumi, medicīnas un bioloğijas progress ir aktuālo izaicinājumu pamatā.

VD teologija 21. gs. ir aizsākusi plašākas diskusijas par VD antropolog̣iju un tās metodologiju, jo 20. gs., pieaugot publikāciju skaitam, metodes pamatā tika aizgūtas no citām humanitārajām nozarēm. Joprojām viens no svarīgākajiem jautājumiem ir VD tekstu antropologiiskās terminologijas pētīšana. Jirgens Oršots (Oorschot) norāda, ka vēl arvien tiek izdotas dažādas teologiiskas vārdnīcas, leksikoni, kuros parasti atrodas vieta arī t. s. antropologískajiem pamatjēdzieniem. ${ }^{25}$ Lai arī VD teksti nepiedāvā sistemātisku antropolog̣iju, tomēr šādu pamatjēdzienu akcentēšana, ko Vāgners pamatoti kritizē un dēvē par redukcionismu, vēl joprojām pastāv. ${ }^{26}$ Jau 60. gados Džeimss Barrs (James Barr) argumentēti parādīja: lai arī valodas ir logiskas, tomēr tās nefunkcionē pēc matemātiskās log̣ikas (īpaši tas attiecas uz dažādiem statistiskiem pētījumiem, kuros mēgina noskaidrot populārāko vārda nozīmi, ko pēc tam vēlas uzspiest citu tekstu gadījumā). ${ }^{27}$ Lai izvairītos no šādas konkrēta termina favorizēšanas, piemēram, Vāgners un Tomass Krīgers (Thomas Krüger) lielu dal̦u antropologisko terminu liek pēdiņās, tādējādi norādot, cik grūti ir tos aptvert, jo uzskata, ka VD antropolog̣ijai nebūtu jānodarbojas ar sarežg̀itīibas reducēšanu

25 Jürgen van Oorschot, "Zur Grundlegung alttestamentlicher Anthropologie - Orientierung und Zwischenruf," in Jürgen van Oorschot (Hg.), Der Mensch als Thema theologischer Anthropologie: Beiträge in interdisziplinärer Perspektive (Neukirchen-Vluyn: Neukirchner Verlag, 2010), 31.

${ }^{26}$ Andreas Wagner, "Wider der Reduktion des Lebendigen: Über das Verhältnis der sog. anthropologischen Grundbegriffe und die Unmöglichkeit, mit ihnen die alttestamentliche Menschenvorstellung zu fassen," in Andreas Wagner (Hg.), Anthropologische Aufbrüche: Anthropologische und interdisziplinäre Zugänge zur historischen Anthropologie (Göttingen: Vandenhoeck \& Ruprecht, 2009), 183-199.

${ }_{27}$ James Barr, The Semantics of Biblical Language (London: Oxford University Press, 1961). 
vai definējošu norobežošanu, - tā vietā ir jāpraktizē daudzbalsīga terminu lietošana, ņemot vērā senebreju valodas attīstības pakāpi. ${ }^{28 .}$

Atsevišksu pētījumu un ar to saistīto diskusiju rezultātā ir kḷuvis skaidrs, ka pieņēmums par kādai kultūrai specifisko iezīmi būtu jāprecizē kāda konkrēta fenomena gadījumā. Piemēram, t. s. sintētiskās domāšanas veids ir raksturīgs ne tikai semītu, bet arī indogermāṇu valodām un kultūrām (heti, grieķi), un, pēc visa spriežot, tas ir fenomens, kas raksturīgs daudzām pasaules tautām. ${ }^{29}$ Tā kā šāds fenomens ir sastopams daudzās valodās, tad šādus izteikumus par ķermeni nav grūti tulkot. Protams, kādā valodā dominēs konkrēti formulējumi (piem., VD - prāts un sirds, latviski - gudra galva), tomēr VD dominē funkcionāli izteikumi, jo senebreju valoda izvairās no abstraktiem jēdzieniem. Ja nevar lietot abstrakciju, tad daudzi izteikumi par ķ kermeni to daudznozīmīguma dēl paliek attiecināti uz ķsermeni.

Apzinoties, ka nav iespējams runāt par vienotu VD antropolog̣iju, aizvien biežāk parādījās publikācijas par konkrētas VD grāmatas (tajā skaitā arī deiterokanoniskas) antropolog̣iju. ${ }^{30}$ Viens no zināmākajiem mēginājumiem ir Bernda Janovska (Bernd Janowski) Psalmu grāmatas antropologija. ${ }^{31}$ Būdams

${ }_{28}$ Thomas Krüger, "Das "Herz" in der alttestamentlichen Anthropologie," in Andreas Wagner (Hg.), Anthropologische Aufbrüche: Anthropologische und interdisziplinäre Zugänge zur historischen Anthropologie (Göttingen: Vandenhoeck \& Ruprecht, 2009), 105. Krīgers atzīmē, ka dažādas iespējamās nozīmes gan nenozīmē, ka tās visas ir iespējamas konkrētajā tekstā, - parasti konteksts diezgan precīzi l̦auj noteikt vārda nozīmi.

29 Pie šāda secinājuma nonāk kāda rakstu krājuma autori Andreass Vāgners un Katrīna Millere (Katrin Müller): Katrin Müller, Andreas Wagner "Das Konzept der synthetischen Körperauffassung in der Diskussion," in Katrin Müller, Andreas Wagner (Hg.), Synthetische Körperauffassung im Hebräischen und den Sprachen der Nachbarkulturen (Münster: Ugarit Verlag, 2014), 233-238.

30 Piemēram, Otto Kaiser, “"Was ist der Mensch und was ist sein Wert?" Beobachtungen zur Anthropologie des Jesus Sirachs nach Jesus Sirach 16,24-18,14," in Michaela Bauks (Hg.), "Was ist der Mensch, dass du seiner gedenkst?" (Psalm 8:5) Aspekte einer theologischen Anthropologie (Neukirchen-Vluyn: Neukirchener Verlag, 2008), 215-225.

31 Bernd Janowski, Konfliktgespräche mit Gott: Eine Anthropologie der Psalmen (Neukirchen-Vluyn: Neukirchener Verlag, 2003). Turpmākajos gados Janovska psalmu antropologija tiek papildināta un atkārtoti izdota (arī daudzās citās valodās). 
Volfa skolnieks, Janovskis lielā mērā turpina viņa iesākto, papildinot ar vēstures antropologỉjas atziñām (vaicājot par cilvēka būtību, ņem vērā vēsturiskos aspektus). Lai izvairītos no senās Israēlas cilvēka nevēsturiskas uztveres, Janovskis no visiem psalmu žanriem izvēlas analizēt konkrētus individuālos vaimanu un pateicības psalmus, jo tie, viņaprāt, uzskatāmi par tipiskiem antropologiskiem tekstiem, kuros skaidri parādās lūdzēju ciešanas. Darba pamatdaḷa sastāv no 8 nodaḷām, kurās aplūkotie psalmi veido cel̦u no dzīvības nāvē un atpakal̦ceḷu no nāves dzīvībā. Lìdzīgi kā Volfs, arī Janovskis katrā nodạ̦ā pievēršas viena vai vairāku antropoloǵisko terminu analīzei. Atšksirībā no Volfa, Janovskis atbilstoši 21. gs. tendencēm pietiekoši bieži atsaucas uz Seno Austrumu paralēlēm (tajā skaitā ikonogrāfiskajām liecībām). Taču, neskatoties uz Janovska veikumu, var piekrist Manfrēdam Ēmingam (Manfred Oeming), ka Janovskim savā darbā nav izdevies atrisināt nevēsturiskuma problēmu, jo grūti iedomāties, ka senajā Israēlā visi lūdza tikai tādā veidā, arī ierobežojums aplūkot tikai vaimanu un pateicības psalmus reprezentē psalmu antropoloǵiju kopumā (piem., līdzīgi kā Volfam, trūkst tautas aspekta - ir psalmi, kuros runā par valdnieku, tautas likteni, Toras nozīmi Israēlam u. tml.). ${ }^{32}$

N̦emot vērā pieredzi psalmu antropologijas raksturošanā, turpmākajos gados Janovskis vairākos rakstos pievēršas personas jēdzienam, ${ }^{33}$ sociālai sfērai un pasaules uztverei VD, lai veiktu priekšdarbus monogrāfijai par visas VD antropologiju ${ }^{34}$. Piemēram, atsevišķ piemēri no dažādiem VD tekstiem tiek analizēti to literārajā un vēsturiskajā kontekstā, lai programmatiski parādītu antropolog̣isko priekšstatu daudzveidību VD. ${ }^{35}$ Janovskis pasvītro, ka attieksme pret pasauli un Dievu raksturo cilvēka būtību, - cilvēka attieksme pret pasauli

${ }_{32}$ Manfred Oeming, Rezension zu Bernd Janowski, Konfliktgespräche mit Gott, Theologische Literaturzeitung 130 (2005): 761.

33 Šroere un Štaubli uzskata, ka senajā Israēlā bija sveši priekšstati par personu vai indivīdu. Thomas Staubli, Silvia Schroer, Menschenbilder der Bibel (Ostfildern: Patmos Verlag, 2014), 11.

${ }_{34}$ Bernd Janovski, "Anthropologie des Alten Testaments: Versuch einer Grundlegung," in Andreas Wagner (Hg.), Anthropologische Aufbrüche, 21.

35 Bernd Janowski, op. cit., 39-40. 
ir taisnīga tikai tad, ja viņš ir atbildīgs par to un apzinās tās radītāju. ${ }^{36}$

Interese par ķ̧ermeni VD teologiijā ir cieši saistīta ar vispārējo sabiedrības interesi par cilvēka k̉ermeni. Vēlme autentiski iepazīt ķ kermeni, interese par vīrieša vai sievietes ķermeņa atšksirībām, sociālā ķ̉ermeņa konstrukcijas, kurās tiek ierakstītas kultūras normas par k̉ermeni, ir tikai dažas no tēmām, kas tiek apskatītas publikācijās. Jau Volfa monogrāfija deva jūtamu ieguldījumu antropolog̣iskās ķ̉ermeņa valodas raksturojumā (izcel̦ot cilvēka miesisko aspektu). Turpmāk pētniecības pārstāvji diezgan aktīvi iesaistījās diskusijā par atsevišksu antropoloǵisko terminu nozīmi ${ }^{37}$ un cilvēka k̉ermenisko eksistenci ${ }^{38}$. Ķermenis, tā ievainojamība un konkrēta vardarbības pieredze VD bieži vien ir izejas punkts dažādiem pētījumiem, piemēram, daudzas pilsētas vai veselas valstis (pazīstamākās - Babilona, Ciāna, Jeruzaleme) attēlotas kā personifikācijas, tāpēc apiešanās ar ķ̧ermeni ir šo tekstu ekseg̉ēzes neatñemama sastāvdaḷa.

Slimībai/veselībai VD ir tikušas veltītas pat atsevišķas konferences. Saskaņā ar pētniecības rezultātiem slimība VD ir vairāk parādīta kā sociāls, nevis medicīnisks fenomens. Slimības iedragā cilvēka kā radības integritāti un, antropologiski raugoties, raksturo to, cik lielā mērā cilvēks ir iesaistīts sabiedrībā vai izolēts no tās (no tā galu galā ir atkarīgas attiecības ar Dievu, slimie netiek pielaisti Jahves kultam).

Emocijas un to atspoguḷošana VD sen jau vairs nav margināla tēma VD antropologijāa, salīdzinot ar 20. gs. pirmo pusi, kad diezgan rezervēti izturējās pret emocionalitāti un to maz pētīja. ${ }^{39}$ Šādi pētījumi palīdz saprast cilvēku individuālo un

${ }^{36}$ Bernd Janowski, op. cit., 40-41.

${ }^{37}$ Piemēram: Jürgen van Oorschot, "Lost in Translation, regain by exegesis: nfš in alttestamentlicher Verwendung und Funktion," in Jürgen van Oorschot, Andreas Wagner (Hg.), Anthropologie(n) des Alten Testaments (Leipzig: Evangelische Verlagsanstalt, 2015), 117-131.

38 Piemēram: Dorothea Erbele-Küster, Körper und Geschlecht: Studien zur Anthropologie von Leviticus 12 und 15 (Neukirchen-Vluyn: Neukirchener Verlag, 2008); Dörte Bester, Körperbilder in den Psalmen: Studien zu Psalm 22 und verwandten Texten (Tübingen: Mohr Siebeck, 2006).

39 Piemēram: Paul A. Kruger, "The Face and Emotions in the Hebrew Bible," Old Testament Essays 18 (2005): 651-663; Paul A. Kruger, "On Emotions and the Expressions of Emotions in the Old Testament: A Few Introductory Remarks," Biblische Zeitschrift 48 (2004): 213-228; 
sociālo dimensiju (piem., no dažādām VD aprakstītām sarunām var spriest par emociju pragmatisko lomu), parāda, kas tajā laikā tika un kas netika uzskatīts par cilvēku sagaidāmo reakciju.

Monogrāfijā par Dieva ķ̌ermeni Vāgners secina, ka priekšstati par Dievu un priekšstati par cilvēku ir daudz ciešāk saistīti, nekā tika uzskatīts līdz šim..$^{40}$ Viena no uzkrītošākajām analog̣ijām ir cilvēka k̦ermeņa daḷu lietošana, runājot par Dievu, tajā pašā laikā jāatzīmē, ka izvēlēto ķ่ermeņa dạ̣u atainošana nav identiska. ${ }^{41}$ Vāgners uzskata, ka ir nepieciešams padziḷināti pētīt, kāpēc Dieva ķ kermeņa attēlojums atšķiras no cilvēka ķermeņa, turklāt šīs atškirīības tikai pieaug vēlīnajos VD tekstos.42 Vāgners brīdina arī par lamatām, tuvojoties šiem tekstiem no mūsdienu pozīcijām, kas var radīt izkroplotu ainu. ${ }^{43}$ Par Dievu VD nerunā abstrakti, arī aiz tādiem izteikumiem kā "augstākais Dievs" vai pat "Tu" slēpjas konkrēti priekšstati. VD cilvēkam Dievs ir personisks, ar viņu veido attiecības, tāpēc tie satur priekšstatus par Dieva ārējo (ķ̣ermeņa) un iekšējo veidolu (rīcība, emocijas).

Kas attiecas uz t. s. VD minēto personu biogrāfiju rakstīšanu, tad pētniecība ir kḷuvusi krietni piesardzīgāka - atsevišksu tēlu gadījumā tā ir literāri konstruēta biogrāfija, lai parādītu kopienas identitāti ar individuāliem vaibstiem (piem., Jahves kalps Jesajas grāmatā).

Pēc tam kad tika publiskoti visās Kumrānas alās atrastie rokraksti, Kumrānas tekstu pētniecība nav izvairījusies no antropoloǵisku jautājumu aplūkošanas, lai gan ir arī objektīvi ierobežojumi to pētīšanai (piem., daudzu tekstu fragmentārais raksturs). ${ }^{44}$

Andreas Wagner, Emotionen, Gefühle und Sprache im Alten Testament: Vier Studien (Waltrop: Hartmut Spenner, 2006).

${ }^{40}$ Andreas Wagner, Gottes Körper: Zur alttestamentlichen Vorstellung der Menschengestaltigkeit Gottes (Gütersloh: Gütersloher Verlagshaus, 2010), 186-188.

${ }_{41}$ Sal. ar: Andreas Vonach, "Gott ähnlich ist nicht Gott gleich: Anmerkungen zu einer angemessenen Anthropologie im Rahmen einer biblischen Theologie," Salzburger Theologische Zeitschrift 13 (2009): 7-19.

${ }^{42}$ Wagner, Gottes Körper, 163-166.

43 Wagner, Gottes Körper, 17-19.

${ }_{44}$ Heinz-Josef Fabry u. a., "Anthropologische Texte aus Qumran und ihre Bedeutung für einen Entwurf qumranitischer Anthropologie," in 
Šo sarakstu varētu vēl turpināt, ${ }^{45}$ taču raksta ierobežotā apjoma dēḷ nākas aprobežoties ar populārākajiem virzieniem VD antropologiijā, kas ir aktuāli šajā gadsimtā.

\section{Nobeigums}

21. gs. VD antropologija turpina 20. gs. pētnieku iesākto darbu, lai teologijāa netiktu izcelti tikai noteikti cilvēka aspekti (piem., 1Moz 1:26-28 un imago Dei), savukārt citus aspektus neignorētu vai nerelativizētu (īpaši tas attiecas uz cilvēka vietu radībā, cilvēka attiecībām ar citām radībām, piem., dzīvniekiem, dzimumu atšksirībām u. c.). Tas nenotiktu, ja analizētu konkrētus tekstus un to antropoloǵisko valodu. Ši gadsimta pētījumi vieš cerību, ka tiek respektēts VD tekstu konteksts un izteikumi par cilvēku VD, kas nav tematiski saistīti, netiek salikti kopā.

VD antropologija 21. gs. pirmajā brīdī var šksist pārāk sadrumstalota, ja VD nav vienotas mācības par cilvēku, tāpēc, sekojot Janovska ieteikumam, vajadzētu nodalìt religisiskos, sociālos un mentālos pamatjautājumus par cilvēka esību, eksistenciālos jautājumus no jautājumiem par cilvēka sūtību/ uzdevumiem.46 Janovski atbalsta Vāgners, jo tas atvieglotu konkrēta VD teksta antropologijas raksturošanu, - viņaprāt, daudzi antropologijas aspekti, kas skar cilvēka būtību, pārklājas daudzās vai visās pozīcijās - šie aspekti bieži vien ir noturīgi un l̦oti lēni piedzīvo izmaiñas. ${ }^{47}$

Tāpat kā citas antropologijas, arī VD antropologija sadarbojas ar citām nozarēm - 21. gs. pētniecībā iezīmējas tendence

Christian Frevel (Hg.), Biblische Anthropologie: Neue Einsichten aus dem Alten Testament (Freiburg im Breisgau: Herder Verlag, 2010), 322-349.

45 Piemēram, klonēšana: Manfred Oeming, "Bioethische Probleme des Klonens in alttestamentlicher und jüdischer Perspektive," Glauben und Lernen 19 (2004): 109-117.

${ }_{46}$ Bernd Janovski, "Anthropologie des Alten Testaments: Versuch einer Grundlegung," in Andreas Wagner (Hg.), Anthropologische Aufbrüche, $39-40$.

${ }_{47}$ Andreas Wagner, "Anthropologie(n) des Alten Testaments im 21. Jahrhundert," in Andreas Wagner (Hg.), Menschenverständnis und Gottesverständnis im Alten Testament (Göttingen: Vandenhoeck \& Ruprecht, 2016), 7. 
akcentēt antropolog̣isko pētījumu starpdisciplinaritāti. ${ }^{48}$ Pētniecība aizvien biežāk analizē VD kā nozīmīgu seno izraēliešu kultūras avotu citu Seno Austrumu kultūru gaismā. Daudzi pamatpriekšstati par cilvēku, piemēram, cilvēka k̦ermeņa dạ̄ām piešksirtās/piedēvētās funkcijas (piem., sirdij - racionalitāte), ir raksturīgi ne tikai VD. ${ }^{49}$ Tie parādās arī citos Seno Austrumu tekstos, kuri nereti ir datējami agrāk par VD tekstiem. No otras puses, pētniecība interesējas arī par VD antropologisko priekšstatu ietekmi uz vēlākām kultūrām un relig̣ijām.

\section{Summary}

\section{Old Testament Anthropology in the 20th and 21st Centuries}

In recent decades the Old Testament anthropology has been flooded with enormous amount of articles on various topics. This article summarizes the research of the Old Testament anthropology in the $20^{\text {th }}$ and $21^{\text {st }}$ centuries and focusses on the main milestones of the research.

Starting from H. W. Wolff's classical book on the Old Testament anthropology, the Old Testament scholarship accepted the complex nature of symbols articulating Israelite understanding and perception of a person. Interdisciplinary and heuristically oriented studies on understanding the individual, constructing identities, body concepts and emotions in the Old Testament lead to reassessment of earlier contributions to the Old Testament anthropology. In the 21st century, a renewed interest in anthropology on the part of the Old Testament scholarship has come as a response to current challenges in science, society, politics etc.

${ }_{48}$ Piemēram: Christian Frevel (Hg.), Biblische Anthropologie: Neue Einsichten aus dem Alten Testament (Freiburg im Breisgau: Herder Verlag, 2010).

${ }_{49}$ Andreas Wagner, "Anthropologie(n) des Alten Testaments im 21. Jahrhundert," in Andreas Wagner (Hg.), Menschenverständnis und Gottesverständnis, 8. 